\title{
Persepsi Mahasiswa pada Pembelajaran Daring melalui Pemanfaatan Google Classroom dan Google Meet di UIN Maulana Malik Ibrahim Malang
}

\author{
Kivah Aha Putra ${ }^{1}$, Ratna Nulinnaja ${ }^{2}$, Misbahul Munir ${ }^{3}$ \\ ${ }^{1,2}$ UIN Maulana Malik Ibrahim Malang, ${ }^{3}$ STAI Ma'had Aly Al-Hikam Malang \\ 1arcillies@uin-malang.ac.id, ${ }^{2}$ ratna_nulinnaja@uin-malang.ac.id \\ ${ }^{3}$ munirmisbahul1990@gmail.com
}

\begin{abstract}
Apart from Coronavirus Disease 2019, Indonesia is now also affected by the mutation of the corona virus B.1.1.7. This means that Indonesia will still struggle to overcome this condition so that it can be stable in all fields. Education, one of which is at the tertiary level, must continue to run stably. To strengthen learning is carried out remotely by utilizing platforms, one of which is using Google Classroom and Google Meet in learning Islamic Cultural History (SPI) to prevent transmission of the Covid 19 virus. This study uses a qualitative method. Through a survey via Google Form which is distributed to students majoring in Physics who are active in the 2020/2021 teaching. The result is that $90.1 \%$ of students are motivated to attend lectures because they do not require a lot of quotas, and the features used on the platform are very easy to operate and very attractive.
\end{abstract}

Keywords: History of Islamic Civilization, Online Learning, Student Perception

\begin{abstract}
Abstrak
Wabah Penyakit virus Corona 2019, Indonesia kini juga terkena dampak mutasi virus corona B.1.1.7. Artinya Indonesia masih akan berjuang mengatasi kondisi ini agar bisa stabil di segala bidang. Pendidikan yang salah satunya di jenjang perguruan tinggi harus terus berjalan dengan stabil. Untuk memperkuat pembelajaran dilakukan dari jarak jauh dengan memanfaatkan platform salah satunya menggunakan Google Classroom dan Google Meet dalam pembelajaran Sejarah Budaya Islam (SPI) untuk mencegah penularan virus Covid 19. Penelitian ini menggunakan metode kuantitatif melalui survei Google Form yang dibagikan kepada mahasiswa jurusan Fisika dan Biologi tahun ajaran 2020/2021. Hasilnya 90,1\% mahasiswa termotivasi untuk mengikuti perkuliahan karena tidak membutuhkan banyak kuota, dan fitur-fitur yang digunakan pada platform sangat mudah dioperasikan dan sangat menarik.
\end{abstract}

Kata Kunci: Pembelajaran Daring, Persepsi Mahasiswa, Sejarah Peradaban Islam 


\section{Pendahuluan}

Pandemi Corona Virus Disease 2019 (Covid-19) di Indonesia masih berlangsung hingga kini. Berkaitan dengan kondisi pandemi global tersebut, Organisasi Kesehatan Dunia (World Health Organization/WHO) menyatakan bahwa masih terlalu dini menyimpulkan pandemi akan berakhir dalam waktu dekat. ${ }^{1}$ Sejalan dengan pernyataan tersebut, Wakil Menteri Kesehatan (Wamenkes) Dante Saksono Harbuwono menyatakan bahwa Indonesia sekarang terdampak juga dengan mutasi virus corona B.1.1.7. Mutasi virus ini pertama kali terdeteksi di Inggris, kini telah ditemukan di Indonesia. ${ }^{2}$ Artinya Indonesia masih berjuang untuk memerangi kondisi agar dapat stabil di segala bidang terutama bidang pendidikan.

Pendidikan merupakan salah satu sektor yang paling terdampak oleh Covid-19. Pendidikan utamanya untuk meningkatkan kualitas suatu negara, oleh karena itu stabilitas pendidikan akan sangat memengaruhi perekonomian dan kesejahteraan masyarakat. Kondisi pendidikan di masa pandemi ini menjadi sulit dan dilematis. Karena proses pembelajaran tatap muka berubah menjadi salah satu faktor penunjang tersebarnya virus secara cepat dan sekaligus menjadi bentuk pelanggaran atas kebijakan penerapan protokol kesehatan yang telah ditentukan oleh pemerintah dan ulama. Pembelajaran tatap muka juga semakin menjadi hal yang tidak relevan karena Indonesia tercatat sebagai salah satu negara dengan penyebaran virus covid 19 terbanyak di Asia Tenggara dan menempati urutan ke 4 di Asia. ${ }^{3}$ Oleh karena itu, kesadaran seluruh lapisan masyarakat untuk mematuhi protokol kesehatan menjadi semakin penting sebagai bentuk usaha bersama untuk menurunkan tingkat penularan Covid-19.

Seluruh jenjang pendidikan terdampak Covid-19, termasuk jenjang pendidikan tinggi. Meski demikian, hal ini bukan berarti proses pendidikan menjadi berhenti. Pemerintah bersama para pendidik memikirkan bagaimana solusi tepat dalam menghadapi kondisi pandemi agar pembelajaran di perguruan tinggi tetap berjalan dengan baik. Kementerian Pendidikan dan Kebudayaan mencatat bahwa setidaknya ada

\footnotetext{
1 Monica Wareza, "Jadi Kapan Covid-19 Hilang Di RI? Ini Studi Ahli," accessed July 3, 2020, https://www.cnbcindonesia.com/tech/20200502121838-37-155803/jadi-kapan-covid-19-hilang-di-ri-inistudi-ahli.

${ }^{2}$ Ahmad Arif, "Mutasi Baru SARS-CoV-2 Dan Konsekuensinya - Kompas.Id," accessed January 3, 2021, https://www.kompas.id/baca/ilmu-pengetahuan-teknologi/2020/12/29/mutasi-baru-sars-cov-2-dankonsekuensinya/.

${ }^{3}$ Luthfia Ayu Azanella, "Kasus Aktif Covid-19 Indonesia Nomor 1 Di ASEAN Dan Peringkat 4 Asia Halaman All - Kompas.Com," accessed September 3, 2020, https://www.kompas.com/tren/read/2020/12/14/171600065/kasus-aktif-covid-19-indonesia-nomor-1-diasean-dan-peringkat-4-asia?page $=$ all.
} 
sekitar 6.3 juta mahasiswa yang menempuh pendidikan tinggi belajar dari rumah. ${ }^{4}$ Berbagai solusi ditawarkan melalui berbagai uji coba dengan melakukan inovasi pembelajaran yang sangat beragam demi mendukung proses perkuliahan agar tetap berjalan stabil. ${ }^{5}$ Berbagai platform dan media pembelajaran digital seketika berubah menjadi sesuatu yang akrab di kalangan dosen/guru dan mahasiswa/siwa karena mempunyai manfaat dan mampu menghidupkan proses perkuliahan yang sesuai dengan karakteristik mahasiswa serta sesuai dengan materi yang akan disampaikan.

Pada pembelajaran daring, proses pembelajaran dapat dikemas melalui berbagai pemanfaatan platform relevan, ekonomis, dan mudah diakses untuk mendukung dan memudahkan proses pembelajaran sehingga mahasiswa mudah menyerap materi pembelajaran yang disampaikan oleh dosen sehingga tujuan pembelajaran dapat tercapai. Pemilihan platform pembelajaran daring menjadi sangat penting karena berimplikasi pada proses interaksi edukatif antara dosen dengan mahasiswa. Oleh karena itu, dosen juga harus tetap mendorong mahasiswa untuk aktif melalui pemberian feedback sehingga proses pembelajaran daring menjadi hidup sebagaimana pembelajaran tatap muka. Dengan demikian, pembelajaran daring menjadi satu-satunya pilihan alternatif bagi keberlangsungan proses pembelajaran pada masa pandemi Covid19 sebagaimana himbauan pemerintah yang mengeluarkan regulasi mengenai kebijakan proses kegiatan pembelajaran dari rumah yang dimaksudkan untuk memutus mata rantai penyebaran virus tersebut. ${ }^{6}$

Sehubungan dengan itu, penelitian tentang hal ini bukan hal baru karena secara umum diketahui bahwa sejak awal pandemi Covid-19 terjadi telah banyak penelitian yang dilakukan mengenai berbagai dampaknya pada berbagai aspek kehidupan dan disiplin keilmuan. Hasil penelitian Zhafira dkk pada Fakultas Ekonomi Universitas TeukuUmar menginformasikan bahwa media pembelajaran daring paling banyak digemari mahasiswa adalah Whatsapp dan Google Classroom karena mayoritas mahasiswa telah mengenal aplikasi tersebut sebelum adanya kebijakan pembelajaran daring secara nasional. ${ }^{7}$

\footnotetext{
${ }^{4}$ Yosepha Pusparisa, "Pandemi Covid-19, Puluhan Juta Murid Belajar Di Rumah | Databoks," 2020, https://databoks.katadata.co.id/datapublish/2020/05/05/pandemi-covid-19-puluhan-juta-siswa-belajar-dirumah.

${ }^{5}$ Misbahul Munir, Pendidikan Era New Normal (Malang: Pustaka Learning Center, 2020).

${ }^{6}$ Nabila Hilmy Zhafira, Yenny Ertika, and Chairiyaton Chairiyaton, "Persepsi Mahasiswa terhadap Perkuliahan Daring sebagai Sarana Pembelajaran," Jurnal Bisnis Dan Kajian Strategi Manajemen 4, no. 1 (April 30, 2020), https://doi.org/10.35308/jbkan.v4i1.1981.

${ }^{7}$ Zhafira, Ertika, and Chairiyaton.
} 
Selanjutnya adalah hasil penelitian Naserly yang menginformasikan tentang berbagai platform yang digunakan dalam proses pembelajaran. Menurutnya, Zoom Meeting sebagai salah satu platform layanan konferensi video yang piawai dijadikan sebagai mdia pembelajaran daring andalan karena mudah digunakan dan menyediakan fitur share screen sehingga pengajar dapat menampilkan bahan ajar layaknya pertemuan tatap muka secara konvensional. Akan tetapi, Zoom kurang ramah kuota internet. Ini berbeda dengan Google Classroom yang dikenal ramah dengan kuota internet karena memang pola akses layanannya didesain layaknya media sosial. Akan tetapi, platform ini tidak menyediakan fitur interaksi dua arah karena pola komunikasinya hanya tersalurkan melalui teks. ${ }^{8}$

Keberadaan pembelajaran daring era pandemi mempunyai hubungan langsung dengan media pembelajaran. Dalam perkembangannya media pembelajaran dapat dikelompokkan menjadi dua jenis yaitu media konvensional dan media digital. Berbagai media pembelajaran daring dengan sendirinya terkategori sebagai media pembelajaran digital yang mudah dipindah melewati platform media lain dan dapat mencakup semua bentuk konten media (gambar, video, audio, dan kombinasinya). ${ }^{9}$ Menurut Yunus, dkk pemberian tugas yang hanya mengandalkan teknologi seperti Whatsapp tanpa dilengkapi media yang memenuhi unsur visual, auditori, dan kinestetik (VAK), dan $\mathrm{read} /$ write (VARK) berpotensi besar pada lemahnya kemampuan pembelajar dalam menyerap pelajaran. ${ }^{10}$ Oleh karenanya, pembelajaran daring sebaiknya tetap mengarah pada usaha mengefektifkan pembelajaran dengan memanfaatkan kombinasi bentuk media dengan memanfaatkan variasi platform yang mampu mendorong aktitifas belajar aktif dan menyenangkan.

Berdasarkan paparan di atas dalam menyikapi persoalan pendidikan masa pandemi Covid-19, maka tulisan ini memfokuskan pada persepsi mahasiswa tentang pembelajaran daring pada proses pembelajaran di UIN Maulana Malik Ibrahim Malang. Mata kuliah ini mempunyai tantangan tersendiri seperti pandangan umum tentang

\footnotetext{
${ }^{8}$ Mursyid Kasmir Naserly, "Implementasi Zoom, Google Classroom, Dan Whatsapp Group Dalam Mendukung Pembelajaran Daring (Online) Pada Mata Kuliah Bahasa Inggris Lanjut (Studi Kasus Pada 2 Kelas Semester 2, Jurusan Administrasi Bisnis, Fakultas Ekonomi Dan Bisnis, Universitas Bina Sarana Informatika Jakarta)," Aksara Public 4, no. 2 (May 30, 2020): 155-65, http://aksarapublic.com/index.php/home/article/view/417.

9 Edi Nurhidin, "Inovasi Pembelajaran Pendidikan Agama Islam (PAI) Melalui Pemanfaatan Media Pembelajaran Kontekstual Dan Pengembangan Budaya Religius Di Sekolah," KUTTAB 1, no. 1 (March 31, 2017): 1-14, https://doi.org/10.30736/kuttab.v1i1.95.

${ }^{10}$ Yunus Busa et al., "Bimbingan Teknis Pembuatan Media Pembelajaran Digital Secara Daring Oleh Civitas Akademika Ditengah Pandemi Covid-19," CARADDE: Jurnal Pengabdian Kepada Masyarakat 3, no. 1 (September 17, 2020): 158-65, https://doi.org/10.31960/caradde.v3i1.501.
} 
pembelajaran sejarah yang membosankan dan tidak jarang membuat mengantuk. ,Mahasiswa saat ini termasuk dalam kategori generasi Z. ${ }^{11}$ Generasi Z hidup dengan kecanggihan teknologi yang begitu pesat, maka dari itu pemanfaatan teknologi yang tepat sangat dibutuhkan dalam proses pembelajaran agar mahasiswa tertarik mengikuti pembelajaran SPI dengan baik.

Proses pembelajaran daring di UIN Maulana Malik Ibrahim Malang pada masa pandemi dilaksanakan dengan menggunakan berbagai platform e-learning. Sebagian besar dosen menggunakan, Google Classroom, Google Meet, Zoom, Media Sosial terutama Whatsapp Group dan Telegram, serta platform lain yang digunakan dalam pembelajaran. ${ }^{12}$ Praktik pembelajaran jarak jauh di UIN Maulana Malik Ibrahim Malang bukan hal yang sama sekali baru karena pernah digunakan pada kondisi normal (sebelum terjadinya pandemi Covid-19). Peneliti dalam hal ini melakukan penelitian pada mata kuliah Sejarah Peradaban Islam di Fakultas Sains dan Teknologi Jurusan Fisika. Proses pembelajaran daring pada mata kuliah SPI berlangsung dengan memanfaatkan dua platform yaitu Google Classroom dan Google Meet. Beberapa indikator yang dapat dijadikan acuan untuk menilai keberhasilan pemanfaatan media dalam sistem pendidikan jarak jauh di antaranya menciptakan motivasi belajar, meningkatkan hasil belajar, membuat mahasiswa mampu mengingat pengetahuan lebih lama, dan memungkinkan mahasiswa mampu menerapkan pengetahuan yang dipelajari. ${ }^{13}$ Oleh karena itu penelitian ini dilakukan untuk mengetahui pandangan mahasiswa terhadap proses pembelajaran dengan menggunakan dua platform pada mata kuliah Sejarah Peradaban Islam (SPI).

\section{Metode}

Penelitian ini menggunakan metode kuantitatif. Teknik pengumpulan data dilakukan melalui survei. Survei dilakukan secara online melalui Google Form yang melibatkan 91 mahasiswa sebagai responden yang terdiri dari mahasiswa pada program studi Fisika dan Biologi. Survei berlangsung mulai tanggal 3 sampai dengan 10 September 2020. Adapun kriteria mahasiswa yang dilibatkan dalam penelitian ini

\footnotetext{
${ }^{11}$ Ranny Rastati, "Media Literasi Bagi Digital Natives: Perspektif Generasi Z Di Jakarta," Kwangsan: Jurnal Teknologi Pendidikan 6, no. 1 (June 29, 2018): 60-73, https://doi.org/10.31800/jtp.kw.v6n1.p60-73.

${ }^{12}$ Umi Salamah, Mohammad Nurul Hajar, and Misbahul Munir, Potret Pendidikan Di Era New Normal (Malang: Pustaka Learning Center, 2020).

${ }^{13}$ F. Adagideli, S. Saraç, and Engin Ader, "Assessing Preschool Teachers' Practices to Promote SelfRegulated Learning *," Undefined, 2015.
} 
adalah mahasiswa aktif pada jurusan Fisika tahun akademik 2020/2021 yang memprogram mata kuliah SPI di UIN Maulana Malik Ibrahim Malang. Komposisi kuesioner terdiri dari tiga bagian yaitu pengantar, identitas responden, dan pertanyaan survei. Pertanyaan survei dikembangkan dengan mengadopsi Biesenbach, ${ }^{14}$ dengan menggali pertanyaan pembuka mencakup aspek kemenarikan dan motivasi dalam mengikuti perkuliahan daring secara mudah, penggunaan media online atau aplikasi pembelajaran daring dengan menggunakan berbagai metode dan strategi dalam google classroom, serta pilihan penggunaan aplikasi pembelajaran daring yang seharusnya dipakai. Analisis data dilakukan secara kuantitatif deskriptif dengan menyajikan persentase yang sudah dihasilkan sendiri oleh aplikasi yang digunakan.

\section{Pembahasan}

Fenomena Pandemi Covid-19 menjadikan institusi pendidikan mendadak menyelenggarakan pembelajaran daring. Pembelajaran daring adalah pembelajaran jarak jauh yang cara penyampaian bahan ajar dan interaksinya dilakukan dengan perantara teknologi internet. ${ }^{15}$ Artinya, keberlangsungan proses pembelajaran daring mensyaratkan ketersediaan jaringan internet yang baik dan stabil serta kesediaan perangkat yang kompatibel seperti laptop atau smartphone demi kelancaran proses pembelajaran. Pada pelaksanaannya, dosen harus paham betul tentang bagaimana merancang pembelajaran daring dengan tetap mempertimbangkan berbagai aspek lain dari kondisi mahasiswa seperti kondisi wilayah yang tercover jaringan internet karena tidak semua mahasiswa tinggal di daerah yang mempunyai jaringan internet yang memadai, tingkat ekonomi mahasiswa, dan kemampuan mereka dalam mengakses berbagai bentuk platform yang dapat digunakan sebagai media pembelajaran daring. Dari sini kemudian dosen harus mempertimbangkan media yang relevan dengan memilih platform yang tepat dalam proses pembelajaran. Pemilihan platform yang tepat bukan hanya pada kesesuaian materi dengan karakteristik mahasiswa melainkan juga platform yang tepat adalah yang tidak membutuhkan terlalu banyak beban kuota akan tetapi yang cukup dalam pemakaian daring tidak memberatkan mahasiswa. Maka pembelajaran daring ini dapat dilakukan secara baik pada pandemi Covid-19 dengan

\footnotetext{
${ }^{14}$ Sigrun Biesenbach-Lucas, "Asynchronous Discussion Groups in Teacher Training Classes: Perceptions of Native and Non-Native Students," Journal of Asynchronous Learning Network, 2003, https://doi.org/10.24059/olj.v7i3.1843.

15 Tim Penyusun, Booklet Pembelajaran Daring, ed. Zahrani Balqis (Jakarta: Direktorat Jenderal Pendidikan Tinggi Kemdikbud R, 2020), 5.
} 
memperhatikan berbagai strategi yang tepat agar menarik dan pemilihan platform yang tepat agar tidak menambah beban mahasiswa dalam mengikuti pembelajaran daring.

Dari hasil survei melalui Google Form diperoleh data yang berkaitan dengan pelaksanaan perkuliahan pada mata kuliah Sejarah Kebudayaan Islam (SPI) secara daring. Kegiatan survei ini juga mempunyai kontribusi penting yang dapat dimanfaatkan sebagai salah satu bahan evaluasi pembelajaran. Populasi survei terdiri dari 81 mahasiswa aktif jurusan Fisika yang mengikuti pembelajaran daring mata kuliah Sejarah Kebudayaan Islam (SPI) dan 10 mahasiswa aktif jurusan Biologi yang mengisi kuesioner Google Form. Jadi survei ini terdiri dari $89 \%$ kelas Fisika dan $11 \%$ kelas Biologi. Terdapat $98.9 \%$ mahasiswa semester 2 dan $1.1 \%$ mahasiswa remedial. Dari hasil survei yang telah dilakukan diketahui bahwa $100 \%$ responden mengakui proses perkuliahan selama masa pandemic Covid-19 berlangsung secara daring. Artinya seluruh civitas academica UIN Maulana Malik Ibrahim Malang mematuhi edaran pemerintah tentang pemberlakuan pembelajaran sistem jarak jauh secara daring yang berkontribusi pada usaha membantu proses penanganan dan pencegahan Covid-19. ${ }^{16}$ Jawaban pertanyaan butir 1 dapat dilihat pada diagram berikut ini:
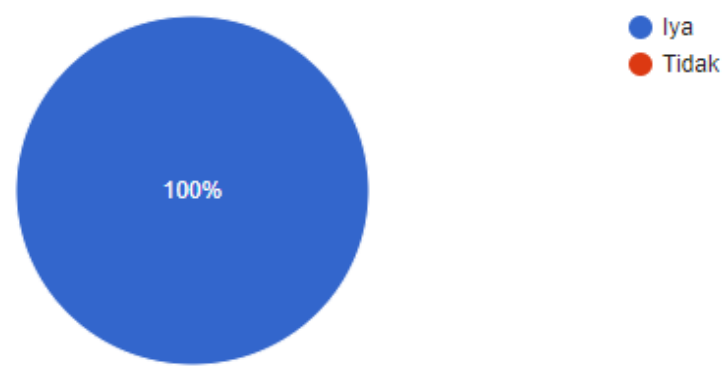

Diagram 1. Tanggapan butir soal no.1

Selanjutnya adalah respon mahasiswa mengenai ketepatan pembelajaran daring. Berdasarkan perolehan data tanggapan mahasiswa pada soal no. 2 ditemukan bahwa terdapat $93.4 \%$ yang menyatakan pemilihan platform sudah tepat, sedangkan sisanya $6.6 \%$ menyatakan kurang tepat. Mengenai respon yang menyatakan kurang tepatnya pemilihan platform ini tentu memerlukan tindak lanjut tersendiri untuk menggali pandangan mereka yang tentunya memerlukan riset lanjutan. Meski demikian, ketidaktepatan pemilihan platform pembelajaran daring memang menjadi konsekuensi karena memang setiap proses pembelajaran mempunyai kelemahan tersendiri

\footnotetext{
${ }^{16}$ Doddy, “Cegah Covid-19, Kampus Didorong Laksanakan Pembelajaran Daring,” Direktorat Jenderal Pendidikan Tinggi Kementerian Pendidikan dan Kebudayaan Republik Indonesia, 2020.
} 
sebagaimana pendapat Rasheed dkk yang menyatakan bahwa pembelajaran daring memang terdapat banyak kelemahan pada prosesnya. ${ }^{17}$ Kelemahan lain pembelajaran daring adalah terkait dengan kurangnya sarana dan prasarana pendukung, faktor ekonomi, dan ketidaksiapan teknologi dalam pelaksanaan kegiatan belajar online. ${ }^{18}$ Berdasarkan beberapa pandangan itu, tampaknya memang tidak bisa mengharuskan mahasiswa untuk semua menjawab tepat dalam pembelajaran daring karena setiap mahasiswa mempunyai selera, cara pandang, dan gaya belajar yang berbeda. Selain itu, kondisi seperti ini juga merupakan hal baru bagi mereka dan membutuhkan waktu untuk membiasakannya. Oleh karena itu, sangat wajar jika terdapat mahasiswa yang masih bingung mengikuti pembelajaran daring atau secara umum berpendapat pembelajaran daring sebagai hal yang kurang tepat dilakukan. ${ }^{19}$ Jawaban pertanyaan butir 2 dapat dilihat pada diagram berikut ini :

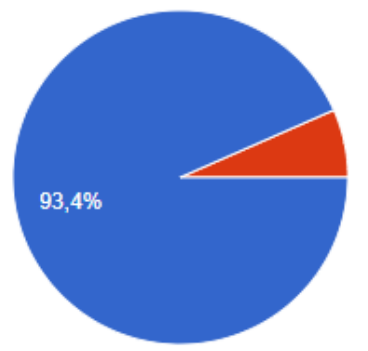

Diagram 2. Tanggapan mahasiswa terhadap ketepatan pembelajaran daring

Berikutnya adalah pandangan mahasiswa tentang kemenarikan dalam penggunaan platform pembelajaran daring. Berdasarkan perolehan data diketahui bahwa sebanyak $81.3 \%$ mahasiswa menyatakan tertarik dalam mengikuti perkuliahan Sejarah Kebudayaan Islam (SPI) sedangkan $18.7 \%$ responden menyatakan kurang tertarik dengan platform yang digunakan dalam pembelajaran online. Artinya lebih banyak mahasiswa yang tertarik dalam penggunaan dua platform ini yaitu Google Classroom dan Google Meet dari pada yang tidak. Google Classroom dimanfaatkan untuk memberikan instruksi mengenai proses pembelajaran yang akan dilakukan pada setiap pertemuan sehingga mahasiswa dapat memahami alur proses pembelajaran yang akan

${ }^{17}$ Rasheed Abubakar Rasheed, Amirrudin Kamsin, and Nor Aniza Abdullah, "Challenges in the Online Component of Blended Learning: A Systematic Review," Computers and Education 144 (January 1, 2020): 103701, https://doi.org/10.1016/j.compedu.2019.103701.

${ }^{18}$ Sulia Ningsih, "Persepsi Mahasiswa Terhadap Pembelajaran Daring Pada Masa Pandemi COVID-19," JINOTEP 7, no. 2 (2020): 124-32, https://doi.org/10.17977/um031v7i22020p124.

19 Jon Chao Hong, Yi Fang Lee, and Jian Hong Ye, "Procrastination Predicts Online Self-Regulated Learning and Online Learning Ineffectiveness during the Coronavirus Lockdown," Personality and Individual Differences 174 (May 1, 2021): 110673, https://doi.org/10.1016/j.paid.2021.110673. 
dilakukan pada tiap pertemuan. ${ }^{20}$ Platform ini juga sangat menarik karena menyediakan fitur yang dapat digunakan untuk pengumpulkan tugas. Dengan kata lain, mahasiswa dapat mengunggah tugas yang diberikan oleh dosen dan tersimpan secara rapi dan dapat diakses kapanpun melalui akun tersebut.

Penggunaan platform tunggal dalam proses pembelajaran tentu mempunyai banyak kelemahan. Terlebih jika platform yang digunakan adalah platform yang tidak mendukung adanya interaksi langsung atau tatap maya. Problem ini dapat diatasi dengan memanfaatkan platform lain yang menyediakan fitur tatap maya. Untuk itu pemilihan platform Google Meet menjadi relevan di sini karena menyediakan fitur tatap maya dan lebih ekonomis yaitu tidak menghabiskan data internet yang banyak dan tidak ada pembatasan waktu sehingga tidak menjadi beban ekonomi tambahan bagi mahasiswa dan dosen. Dengan fitur tatap maya, proses diskusi dan tanya-jawab dapat dilakukan lebih baik dari pada diskusi tulis menulis melalui chat WAG atau Telegram. Dosen juga bisa memberikan feedback langsung dan memberikan kemudahan untuk mengamati aktifitas mahasiswa secara langsung dan lebih nyata. Dalam hal ini, Rusdiana dan Nugroho menyatakan bahwa kelas virtual yang terkoneksikan melalui teks semakin mengurangi makna interaksi antara pengajar dan pembelajar, tentu akan sangat berbeda jika dibandingkan dengan penggunaan aplikasi Zoom Meeting walaupun sifat interaksi virtualnya bersifat daring. ${ }^{21}$

Dengan demikian, pemanfaatan kedua platform ini menjadi relevan digunakan untuk memperlancar proses pembelajaran daring selama pandemi Covid-19. Penggunaannya juga erat kaitannya dengan pemilihan bentuk media pembelajaran yang saling melengkapi untuk meminimalkan tingkat kejenuhan mahasiswa yang sekaligus mendorong motivasi mereka untuk mengikuti perkuliahan secara daring. Di mana fitur yang tidak tercover oleh Google Classroom yang tidak menyediakan sisi interaktif proses pembelajaran dapat teratasi oleh fitur yang ada pada Google Meet. Sehingga proses pembelajaran daring tetap dapat berlangsung secara interaktif melalui tatap maya melalui layar laptop atau smartphone masing-masing. Berikut ini diagram tentang respon mahasiswa mengenai kemenarikan platform yang digunakan:

\footnotetext{
${ }^{20}$ Natsagdorj Bayarmaa and Keunsoo Lee, "A Study on the Application of Google Classroom for Problem-Based Learning," Journal of Korea Academia-Industrial Cooperation Society 19, no. 7 (2018): 81-87, https://doi.org/10.5762/kais.2018.19.7.81.

21 Emmilia Rusdiana and Arianto Nugroho, "Respon Mahasiswa Pada Pembelajaran Daring Bagi Mahasiswa Mata Kuliah Pengantar Hukum Indonesia UNESA," Integralistik 31, no. 1 (March 8, 2020): 1-12, https://doi.org/10.15294/integralistik.v31i1.21834.
} 


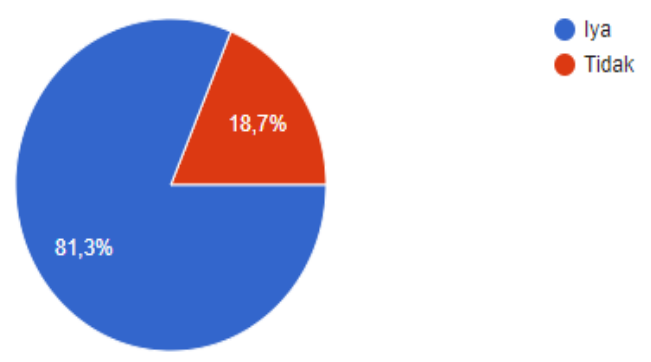

Diagram 3. Tanggapan mahasiswa terhadap kemenarikan platform

Kuesioner no. 4 berkaitan dengan tingkat motivasi mahasiswa menggunakan Google Classroom dan Google Meet dalam pembelajaran daring. Diperoleh hasil 90,1\% mahasiswa termotivasi mengikuti perkuliahan karena fitur yang ada di Google Classroom mempunyai tampilan menarik dan mudah digunakan. Memperhatikan tingkat motivasi dalam penggunaan platform sangat penting untuk jembatan dalam menghubungkan kognisi mahasiswa, menghubungkan pandangan mahasiswa, dan pengalaman baru terhadap materi yang akan dipelajari, serta menghubungkan dunia mahasiswa dengan dunia dosen agar tercipta sebuah sinkronisasi sebelum memulai kegiatan pembelajaran. ${ }^{22}$ Berikut ini diagram tentang respon mahasiswa mengenai hal tersebut:

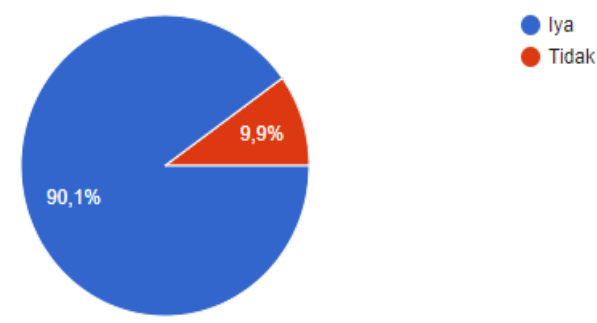

Diagram 4. Tanggapan mahasiswa terhadap tingkat motivasi menggunakan platform

Terakhir adalah tentang tanggapan mahasiswa yaitu apakah mereka ingin mempertahankan pembelajaran menggunakan platform Google Classroom dan Google Meet atau memiliki menggunakan platform lain. Diperoleh data sebanyak $58.2 \%$ mahasiswa ingin tetap menggunakan Google Classroom dan Google Meet. Bagi mereka, alasan utamanya adalah untuk menghemat kuota dan fiturnya menarik. Sedangkan $41.8 \%$ mahasiswa memberikan jawaban terbuka ingin berganti ke platform lain seperti whatsapp, telegram maupun edmodo. Setiap platform memang memiliki

${ }^{22}$ Affa Ardhi Saputri, "Mengembangkan Teknik Apersepsi Dan Motivasi Pada Pembelajaran Daring," Fakultas Sains dan teknologi UIN Walisongo Semarang, n.d. 
kekurangan tak terkecuali dengan whatsapp maupun telegram, penyimpanan data dalam bentuk percakapan yang kurang rapi menjadikan data terkadang tertumpuk dan sulit terakses. Akan tetapi sejauh ini pendapat mahasiswa tentang penggunaan platform dalam pembelajaran daring Sejarah Peradaban Islam (SPI) sangat mendukung dan positif. Hasil yang diperoleh juga didukung oleh penelitian terdahulu menunjukkan bahwa penggunaan Google Classroom cukup efektif dalam pembelajaran sejarah kebudayaan Islam ditinjau dari hasil belajar siswa. ${ }^{23}$

Dari uraian di atas, maka dapat disimpulkan bahwa dosen harus mampu menyusun desain perkuliahan serta dapat memiliih platform media sesuai dengan karakteristik mata kuliah yang diampu. Hal ini agar interaksi edukatif antara dosenmahasiswa, sesama mahasiswa, dan sesama dosen dapat tetap terjaga. Google Classroom dengan berbagai fitur-fitur yang dimilikinya menjadi pilihan terbaik dalam menjaga keberlangsungan perkuliahan serta menjaga interaksi edukatif tetap eksis sebagaimana yang berlaku pada perkuliahan offline. ${ }^{24}$ Persentase respon mahasiswa mengenai keinginan menggunakan platform lain dapat dilihat pada diagram berikut ini:

91 tanggapan

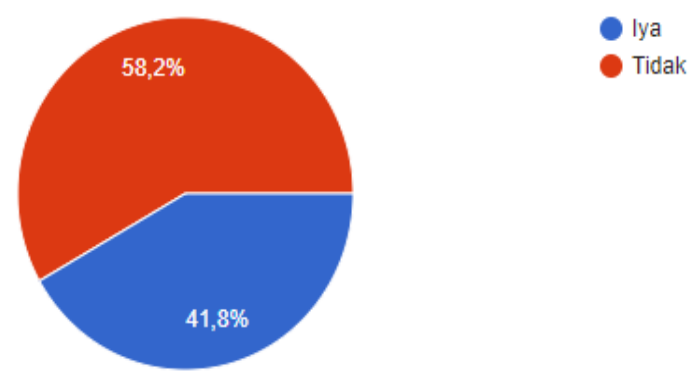

Diagram 5. Tanggapan mahasiswa terhadap keinginan menggunakan platform lain

\section{Penutup}

Berdasarkan survei dari kuesioner yang disebar di jurusan Fisika semester 2 tentang persepsi mahasiswa terhadap penggunaan Google Classroom dan Google Meet dalam pembelajaran daring maka dihasilkan $100 \%$ proses pembelajaran dilakukan secara daring penuh, pada butir ketepatan platform media pembelajaran daring didapatkan $93.4 \%$ menjawab sudah tepat platform yang digunakan dan $18.7 \%$

\footnotetext{
${ }^{23}$ Ossi Marga Ramadhan and Tarsono Tarsono, "Efektifitas Pembelajaran Sejarah Kebudayaan Islam Melalui Google Classroom Ditinjau Dari Hasil Belajar Siswa," JINoP (Jurnal Inovasi Pembelajaran) 6, no. 2 (2020): 204-14, https://doi.org/10.22219/jinop.v6i2.12927.

${ }^{24}$ Ambiyar, "Aspek Interaksi Akademik Dalam Perkuliahan Daring Google Classroom Di Program Studi Sejarah Dan Peradaban Islam Fakultas Adab Dan Humaniora UIN Imam Bonjol Padang," Khazanah: Jurnal Sejarah Dan Kebudayaan Islam, 2019, 41-50.
} 
menjawab kurang tepat platform yang digunakan. Untuk kemenarikan dalam penggunaan platform media diperoleh $81.3 \%$ menjawab menarik sedangkan $18.7 \%$ kurang tertarik dan perlu adanya alternatif platform lain. Kuesioner terkait motivasi belajar mahasiswa meningkat ketika mengikuti perkuliahan menggunakan kedua platform tersebut didapat $90.1 \%$ mahasiswa termotivasi untuk mengikuti perkuliahan Sejarah Kebudayaan Islam (SPI) dengan menggunakan kedua platform tersebut karena fitur-fitur yang dipakai dalam Google Clasroom dan Google Meet sangat mudah untuk dioperasikan serta sangat menarik. Kuesioner terkait tawaran penggunaan platform lain dalam perkuliahan didapat $58.2 \%$ mahasiswa tetap untuk menggunakan kedua platform tersebut, sedangkan $41.8 \%$ mahasiswa menginginkan ada alternatif platform media daring lainnya. Dari sini tampak bahwa secara umum kedua platform ini merupakan salah satu pilihat yang tepat digunakan yaitu tidak hanya tepat pada kesesuaian materi, ataupun dengan karakteristik mahasiswa melainkan juga platform yang tepat karena tidak membutuhkan terlalu banyak beban kuota yang besar akan tetapi cukup dalam pemakaian daring yang tidak memberatkan mahasiswa.

\section{Daftar Rujukan}

Adagideli, F., S. Saraç, and Engin Ader. "Assessing Preschool Teachers' Practices to Promote Self-Regulated Learning *.” Undefined, 2015.

Ambiyar. “Aspek Interaksi Akademik Dalam Perkuliahan Daring Google Classroom Di Program Studi Sejarah Dan Peradaban Islam Fakultas Adab Dan Humaniora UIN Imam Bonjol Padang.” Khazanah: Jurnal Sejarah Dan Kebudayaan Islam, 2019, 41-50.

Arif, Ahmad. "Mutasi Baru SARS-CoV-2 Dan Konsekuensinya - Kompas.Id." Accessed August 3, 2020. https://www.kompas.id/baca/ilmu-pengetahuanteknologi/2020/12/29/mutasi-baru-sars-cov-2-dan-konsekuensinya/.

Azanella, Luthfia Ayu. "Kasus Aktif Covid-19 Indonesia Nomor 1 Di ASEAN Dan Peringkat 4 Asia Halaman All - Kompas.Com.” Accessed September 3, 2020. https://www.kompas.com/tren/read/2020/12/14/171600065/kasus-aktif-covid19-indonesia-nomor-1-di-asean-dan-peringkat-4-asia?page=all .

Bayarmaa, Natsagdorj, and Keunsoo Lee. "A Study on the Application of Google Classroom for Problem-Based Learning." Journal of Korea Academia-Industrial $\begin{array}{lllll}\text { Cooperation Society } & 19, & \text { no. } & 7 & \text { (2018): }\end{array}$ https://doi.org/10.5762/kais.2018.19.7.81.

Biesenbach-Lucas, Sigrun. "Asynchronous Discussion Groups in Teacher Training Classes: Perceptions of Native and Non-Native Students." Journal of Asynchronous Learning Network, 2003. https://doi.org/10.24059/olj.v7i3.1843.

Busa, Yunus, Agusriandi, Elihami, and Mutmainnah. "Bimbingan Teknis Pembuatan Media Pembelajaran Digital Secara Daring Oleh Civitas Akademika Ditengah 
Pandemi Covid-19." CARADDE: Jurnal Pengabdian Kepada Masyarakat 3, no. 1 (September 17, 2020): 158-65. https://doi.org/10.31960/caradde.v3i1.501.

Doddy. "Cegah Covid-19, Kampus Didorong Laksanakan Pembelajaran Daring." Direktorat Jenderal Pendidikan Tinggi Kementerian Pendidikan dan Kebudayaan Republik Indonesia, 2020.

Hong, Jon Chao, Yi Fang Lee, and Jian Hong Ye. "Procrastination Predicts Online SelfRegulated Learning and Online Learning Ineffectiveness during the Coronavirus Lockdown." Personality and Individual Differences 174 (May 1, 2021): 110673. https://doi.org/10.1016/j.paid.2021.110673.

Munir, Misbahul. Pendidikan Era New Normal. Malang: Pustaka Learning Center, 2020 .

Naserly, Mursyid Kasmir. "Implementasi Zoom, Google Classroom, Dan Whatsapp Group Dalam Mendukung Pembelajaran Daring (Online) Pada Mata Kuliah Bahasa Inggris Lanjut (Studi Kasus Pada 2 Kelas Semester 2, Jurusan Administrasi Bisnis, Fakultas Ekonomi Dan Bisnis, Universitas Bina Sarana Informatika Jakarta)." Aksara Public 4, no. 2 (May 30, 2020): 155-65. http://aksarapublic.com/index.php/home/article/view/417.

Ningsih, Sulia. "Persepsi Mahasiswa Terhdap Pembelajaran Daring Pada Masa Pandemi COVID-19." JINOTEP 7, no. 2 (2020): 124-32. https://doi.org/10.17977/um031v7i22020p124.

Nurhidin, Edi. "Inovasi Pembelajaran Pendidikan Agama Islam (PAI) Melalui Pemanfaatan Media Pembelajaran Kontekstual Dan Pengembangan Budaya Religius Di Sekolah.” KUTTAB 1, no. 1 (March 31, 2017): 1-14. https://doi.org/10.30736/kuttab.v1i1.95.

Penyusun, Tim. Booklet Pembelajaran Daring. Edited by Zahrani Balqis. Jakarta: Direktorat Jenderal Pendidikan Tinggi Kemdikbud R, 2020.

Pusparisa, Yosepha. "Pandemi Covid-19, Puluhan Juta Murid Belajar Di Rumah | Databoks," 2020. https://databoks.katadata.co.id/datapublish/2020/05/05/pandemi-covid-19puluhan-juta-siswa-belajar-di-rumah.

Ramadhan, Ossi Marga, and Tarsono Tarsono. "Efektifitas Pembelajaran Sejarah Kebudayaan Islam Melalui Google Classroom Ditinjau Dari Hasil Belajar Siswa." JINoP (Jurnal Inovasi Pembelajaran) 6, no. 2 (2020): 204-14. https://doi.org/10.22219/jinop.v6i2.12927.

Rasheed, Rasheed Abubakar, Amirrudin Kamsin, and Nor Aniza Abdullah. "Challenges in the Online Component of Blended Learning: A Systematic Review." Computers and Education 144 (January 1, 2020): 103701. https://doi.org/10.1016/j.compedu.2019.103701.

Rastati, Ranny. "Media Literasi Bagi Digital Natives: Perspektif Generasi Z Di Jakarta." Kwangsan: Jurnal Teknologi Pendidikan 6, no. 1 (June 29, 2018): 6073. https://doi.org/10.31800/jtp.kw.v6n1.p60--73.

Rusdiana, Emmilia, and Arianto Nugroho. "Respon Mahasiswa Pada Pembelajaran Daring Bagi Mahasiswa Mata Kuliah Pengantar Hukum Indonesia UNESA." Integralistik 31, no. 1 (March 8, 2020): 1-12. https://doi.org/10.15294/integralistik.v31i1.21834. 
Salamah, Umi, Mohammad Nurul Hajar, and Misbahul Munir. Potret Pendidikan Di Era New Normal. Malang: Pustaka Learning Center, 2020.

Saputri, Affa Ardhi. "Mengembangkan Teknik Apersepsi Dan Motivasi Pada Pembelajaran Daring." Fakultas Sains dan teknologi UIN Walisongo Semarang, n.d.

Wareza, Monica. “Jadi Kapan Covid-19 Hilang Di RI? Ini Studi Ahli.” Accessed July 3, 2020. https://www.cnbcindonesia.com/tech/20200502121838-37-155803/jadikapan-covid-19-hilang-di-ri-ini-studi-ahli.

Zhafira, Nabila Hilmy, Yenny Ertika, and Chairiyaton Chairiyaton. "Persepsi Mahasiswa terhadap Perkuliahan Daring sebagai Sarana Pembelajaran.” Jurnal Bisnis Dan Kajian Strategi Manajemen 4, no. 1 (April 30, 2020). https://doi.org/10.35308/jbkan.v4i1.1981. 